III Encuentro Bienal de Investigación y Postgrado 2016 / Ciencia y Tecnología III Research and Postgraduate Biennial Encounter 2016 / Science and Technology

\title{
T28 - DSP2DSB: Distinción de emisiones de radio solares en imágenes de espectros dinámicos
}

\author{
Felipe Meza*, Luis Crespo \\ Maestría en Ingeniería Electrónica DSP, Instituto Tecnológico de Costa Rica
}

*Autor al que se dirige la correspondencia: fmezacr@gmail.com

\section{Resumen}

T os datos fundamentales en la radioastronomía, corresponden a señales de radio frecuencia generadas en el Lespacio exterior, una de las fuentes más importantes es el Sol. Tales emisiones se clasifican en varios tipos, desafortunadamente muchos de los procesos actuales de clasificación se llevan a cabo de forma manual, y esto crea un nivel importante de complejidad para su identificación, especialmente en los casos donde hay grandes cantidades de ruido, algo muy común en aplicaciones de radio frecuencia. Se propone un sistema denominado DSP2DSB (por sus siglas en inglés (Digital Signal Processing to Distinguish Solar Burst) para la clasificación de emisiones solares en baja frecuencia tipo II y III.

Palabras claves: Emisiones, radioastronomía, wavelets, naive Bayes, morfología

\begin{abstract}
$\mathrm{T}$ he fundamental data of radioastronomy are the radio frequency signals originated in outer space, one of the most important sources is the Sun. These radio emissions can be classified in several types; unfortunately, most of the currently classification processes are done manually, and that creates an important level of complexity to identify the type of emission; especially in cases where data has significant amounts of noise which is very common in radio frequency applications. In this presentation we propose an approach called DSP2DSB (Digital Signal Processing to Distinguish Solar Burst) to classify type II and III solar bursts in low frequencies.
\end{abstract}

Keywords: Solar emissions, radioastronomy, wavelets, naive Bayes, morphology sobre protección a los derechos de autor, con criterio especificados en la licencia Creative Commons (CC BY-NC-SA 4.0) 